\title{
Dampak IT terhadap hubungan antara strategi dan kinerja perusahaan
}

Nama: Muhammad.Alvin.Arkananta.Syam

Email: alvinas2751@gmail.com

Internet sudah mengakar di kehidupan kita ini, semua kegiatan yang dilakukan setiap hari hampir semuanya ada sangkut paut dengan internet bahkan sekarang kipas angin bisa dihidupkan hanya dengan ucapan "hidupkan kipas angin" yang biasanya disupport dengan google assistant atau siri. Salah satu hal yang penting adalah Informasi Teknologi. Dalam studi (Pratono, 2016) menyatakan bahwa adanya sebuah hubungan heterogen antara Orientasi Strategi dan Kinerja Perusahaan yang tercipta dari penambahan Turbulensi Teknologi sebagai faktor kontingensi primer, Orientasi pasar akan bersifat responsif saat turbulensi teknologi berada di tingkat tinggi dan Kemampuan Dinamis Turbulensi Teknologi bisa menawarkan efek yang lebih susah untuk dipahami kepada UKM dengan tanda kutip "Untuk mendapatkan peluang pasar dengan berbagai Kedinamisan Turbulensi Teknologi, UKM bisa saja melakukan investasi besar-besaran dalam penelitian dan pengembangan untuk memanfaatkan peluang pasar tersebut dengan konsekuensi mungkin mereka (UKM) akan menderita kinerja yang buruk dibawah Turbulensi Teknologi yang tinggi, Kinerja UKM sendiri berasal dari strategi yang berbasis peluang tetapi harus diingat juga UKM bergantung pada informasi Turbulensi Teknologi dan hasilnya menunjukkan bagaimana Turbulensi Teknologi bisa mempengaruhi proses pengambilan keputusan manajerial di bawah sudut pandang yang berbasis peluang (Pratono, 2016)

\section{Daftar Pustaka}

Pratono, A. H. (2016, Maret 4). Strategic orientation and information technological turbulence: Contingency perspective in SMEs. Business Process Management Journal, 22(2), 368-382. 